\title{
Adenomyoepithelial Adenosis of the Breast: Clinical, Radiological, and Pathological Findings for Differential Diagnosis
}

\author{
Serap Erela Isil Tuncbilek $^{b} \quad$ Kemal Kismet $^{\mathrm{a}} \quad$ Bulent Kilicoglu $^{\mathrm{a}} \quad$ Elif Ozer $^{\mathrm{c}} \quad$ Mehmet Ali Akkus $^{\mathrm{a}}$ \\ a 4th General Surgery Department,

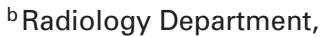 \\ c Pathology Department, Ankara Training and Research Hospital, Turkey
}

\section{Key Words}

Breast cancer - Adenomyoepithelial adenosis . Adenomyoepithelioma - Myoepithelial lesions

\section{Summary}

Background: Myoepithelial cells are widely present in the breast, and their hyperplasia may result in a spectrum of disease ranging from myoepitheliosis to myoepithelial carcinoma. Case Report: A 46-year-old woman presented with a palpable mass in her right breast. Mammography and ultrasonography showed a lesion in the upper quadrant of the right breast with spiculated borders and shape. Excisional biopsy showed adenomyoepithelial adenosis. Conclusions: Although considered benign, adenomyoepithelial lesions tend to recur due to inadequate excision. Therefore, possibility of recurrence and even metastasis should be considered during follow-up of patients with a diagnosis of adenomyoepithelial lesions.

\section{Introduction}

Hyperplastic and neoplastic lesions of the breast usually arise from atypical proliferation of epithelial cells [1]. Myoepithelial cells are widely present in the breast, and their hyperplasia may result in a spectrum of disease ranging from myoepitheliosis to myoepithelial carcinoma [2]. Adenomyoepithelial adenosis was shown to reveal high proliferative activity in both glandular epithelial and myoepithelial cells and was con-

\section{Schlüsselwörter}

Brustkrebs - Adenomyoepitheliale Adenose .

Adenomyoepitheliom · Myoepitheliale Läsionen

\section{Zusammenfassung}

Hintergrund: Myoepitheliale Zellen sind überall in der Brust zu finden. Eine Hyperplasie dieser Zellen kann zu einem weiten Erkrankungsspektrum von Myoepitheliose bis hin zu myoepithelialen Karzinomen führen. Fallbericht: Eine 46-jährige Frau wurde mit einer tastbaren Geschwulst in der rechten Brust vorstellig. Die mammographische und Ultraschalluntersuchung zeigten eine Läsion mit spikulierter Begrenzung und Form im oberen Quadranten der rechten Brust. Die Untersuchung der Exzisionsbiopsie ergab eine adenomyoepitheliale Adenose. Schlussfolgerungen: Adenomyoepitheliale Läsionen gelten zwar als gutartig, auf Grund unvollständiger Entfernung rezidivieren sie aber häufig. Deshalb sollte das mögliche Auftreten von Rezidiven und sogar Metastasen während des Follow-ups von Patienten mit adenomyoepithelialen Läsionen im Auge behalten werden.

sidered to be prone to progress to obvious carcinoma $[2,3]$. Adenomyoepithelial adenosis can be well circumscribed or consist of multiple foci of randomly arranged ductules with luminal secretion, similar to microglandular adenosis. The simultaneous alteration and hypertrophy of epithelial and myoepithelial cells is a hallmark of adenosis, particularly adenomyoepithelial adenosis [4]. In this paper, a case of adenomyoepithelial adenosis is reported and discussed on the basis of clinical, radiological, and pathological findings.

\section{KARGER}

Fax +497614520714

Information@Karger.de

www.karger.com (c) 2008 S. Karger GmbH, Freiburg

Accessible online at:

www.karger.com/brc

4th General Surgery Department

Cebeci, Ankara, Turkey

Tel. +90 312-5953000, Fax -3633396

sererel@yahoo.com 


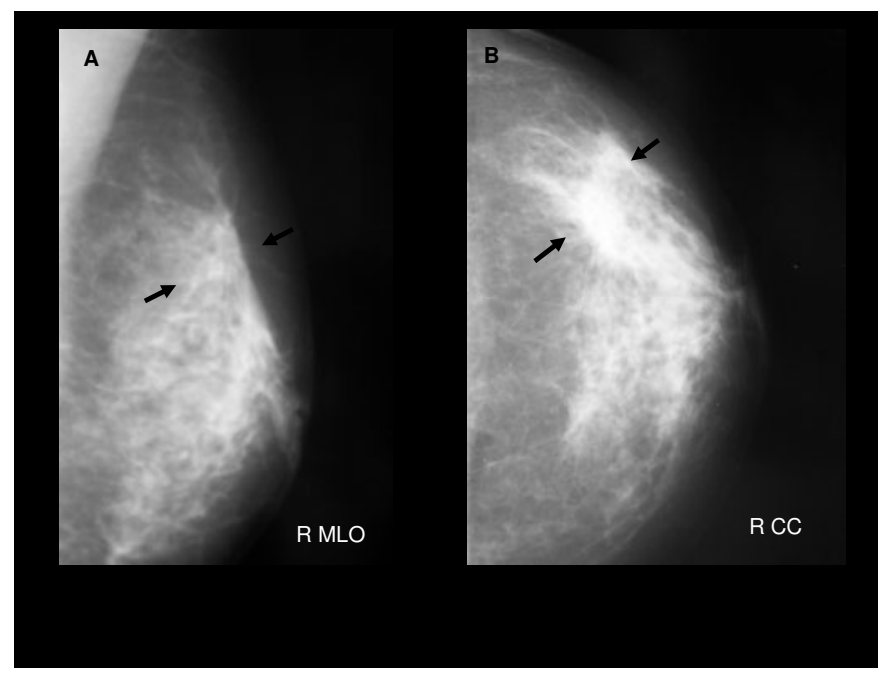

Fig. 1. A $M L O$ and $\mathbf{B} C C$ mammograms of the patient. An irregular spiculated dense mass (arrows) is seen in the upper outer quadrant of the right breast.

\section{Case Report}

A 46-year-old woman presented with a right breast lump that had been palpable for 2 months. She did not have any history of cancer or exposure to radiotherapy. The family history of the patient revealed no cases of breast cancer. She had been under treatment for mastalgia for 6 months. She was referred to our hospital for a diagnostic mammography and ultrasonography (USG). Bilateral mammography showed an irregularly shaped mass with spiculated margins and associated pleomorphic microcalcifications in the upper quadrant of the right breast (fig. 1). USG showed an irregular spiculated hypoechoic mass of $12 \times 13 \mathrm{~mm}$ with posterior acoustic shadowing (fig. 2). The radiological features of the lesion were defined as highly suggestive of malignancy (BI-RADS 5). There were also enlarged axillary lymph nodes on both sides. The biggest lymph node in the right axilla demonstrated ultrasonographic features suspicious for malignancy. Excisional biopsy of the breast mass was performed by another department of our hospital. The pathology report revealed fibrocystic changes. As no radiological-pathologic correlation was found, USG was repeated, and the mass was shown to be persisting.

The patient was referred to our department for re-excision. On physical examination, the mass was palpable under the incisional scar. We in formed the patient about biopsy techniques including core biopsy, but due to anxiety she decided to undergo excisional biopsy. Excisional biopsy was performed. A specimen mammogram was taken for approval of complete excision. Since microcalcifications were observed close to the resection margin, we re-excised an at least $1 \mathrm{~cm}$ wide rim of normal tissue to provide clear margins. Histopathology showed diffuse proliferation of round or irregular tubular structures lined by a cuboidal to columnar epithelium. There was a prominent focally hyperplastic myoepithelial cell layer with strikingly clear cytoplasm. There was no significant nuclear atypia or mitotic activity (figs. 3 and 4). Immunocytochemical staining showed positive staining with SMA, S100, p63, and high keratin in myoepithelial cells (fig. 5). These appearances were diagnostic for adenomyopethelial adenosis. Fine needle aspiration cytology (FNAC) obtained from axillary lymphadenopathies under USG guidance showed no evidence of malignancy. Therefore, we decided to follow up the patient for her axillary lymphadenopathies. In her control USG, the dimensions of the lymph nodes have regressed to $4 \times 6 \mathrm{~mm}$. There is no evidence of recurrence and lymphadenopathy for 10 months from her last surgery.
Fig. 2. Ultrasonography of the right breast confirms an irregular spiculated hypoechoic mass.

Fig. 3. The myoepithelial cells are increased in size and surrounding the ductus $(\mathrm{H}$ and $\mathrm{E} \times 200)$.

Fig. 4. Solid islands consisting of myoepithelial cells $(\mathrm{H}$ and $\mathrm{E}$ $\times 200$ ).

Fig. 5. Positive brown SMA staining in the myoepithelial cytoplasm.
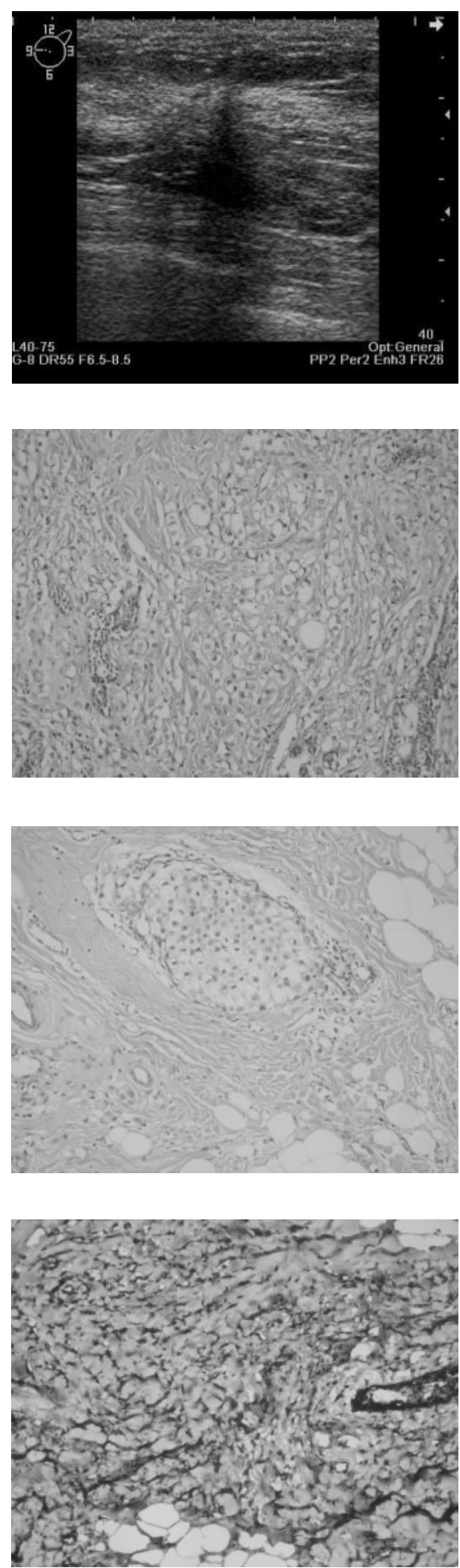

\section{Discussion}

Adenomyoepithelial lesions frequently appear in the salivary gland, skin, and parathyroid [5, 6]. Myoepithelial cells are normally present in the breast, and are located between the luminal cells and the basal lamina of ductules. Tavassoli [3] classified the myoepithelial lesions of the breast as myoepitheliosis, adenomyoepithelioma, and malignant myoepithelioma (my- 
oepithelial carcinoma). She also subdivided adenomyoepitheliomas according to their cell predominance as spindle cells, tubular, lobulated, and carcinoma arising in adenomyoepithelioma. Pia-Foschini et al. [7] suggested that it may be more appropriate to abandon the use of apocrine adenosis (adenomyoepithelial adenosis) and to report these lesions as tubular adenomyoepithelioma. Moinfar [4] described adenomyoepithelial adenosis as a rare variant of adenosis with a prominent myoepithelial component within the involved glands (hypertrophy and/or hyperplasia of myoepithelial cells). The tubules show a prominent myoepithelial cell component. The luminal epithelial cells and basally located myoepithelial cells not infrequently show enlarged nuclei and prominent nucleoli. Apocrine or squamous metaplasia may be present. Adenomyoepithelial adenosis cannot reliably be separated from a small (microscopic) adenomyoepithelioma [4]. The heterogeneous cell population with simultaneous hypertrophy of epithelial and myoepithelial cells in our case proves the lesion's benign nature.

The typical histological appearance of a benign adenomyoepithelioma consists of acinar structures composed of an inner layer of epithelial cells with eosinophilic cytoplasm surrounded by prominent myoepithelial cells [1]. The myoepithelial cells frequently have clear cytoplasm and are shown to be positive for smooth muscle myosin, S100 protein, and actin [8]. Adenomyoepitheliomas present as a palpable, sometimes tender and peripherally located masses [7]. Imaging may demonstrate malignant features but no uniform criteria were reported to differentiate benign adenomyoepitheliomas from malignant ones. The gross sizes range from 0.5 to $5 \mathrm{~cm}$ (median $1.5 \mathrm{~cm}$ ) [9]. Howlett et al. [10] described the imaging features for discrimination of benign from malignant adenomyoepithelioma. Benign adenomyoepitheliomas have smooth margins without any structural abnormalities in the surrounding tissue. Malignant ones are irregularly bordered lesions with surrounding structural abnormalities, and posterior shadowing at ultrasonography was also demonstrated. In our patient, the sonographic and mammographic appearances suggested malignancy. Breitwieser et al. [11] for the first time demonstrated a benign adenomyoepithelioma characterized by magnetic resonance (MR) mammography and confirmed by MR-guided vacuum-assisted biopsy. The time course of signal enhancement determined by MR imaging gave information suggestive for malignant transformation, while the appearance on $\mathrm{T} 2$ weighted images was indicative of a benign lesion.

Adenomyoepitheliomas are rare and may show wide variations, and they may be confused with other myoepithelial/ stromal cell-rich structures that mimic this lesion. Therefore, a core biopsy should be preferred to FNAC $[12,13]$. Yahara et al. [9] reported that after excision of the lesion by mammotome biopsy, they provided an exact diagnosis and complete removal of benign adenomyoepithelioma. Although in our case core biopsy or stereotactic biopsy were recommended by radiologists, our patient preferred total excision which pro- vided an exact diagnosis and surgical treatment in the same operation. Specimen mammography obtained after resection of the lesion enabled us to provide clear margins for complete treatment by supplying information about the margins of the excisional biopsy. We decided to follow up our patient's lymphadenopathies since benign adenomyoepitheliomas have a low tendency to develop axillary lymph node metastasis [3]. On control USG and physical examination, the lymphadenopathies had almost disappeared. The patient has been symptom-free for 10 months.

As both benign and malignant adenomyoepitheliomas have a tendency to recur, re-excision is recommended in cases of suspected inadequate margins [14]. The best predictors of recurrence are initial incomplete or close excision margins. Therefore, correct preoperative diagnosis is important for surgical planning. Myoepithelial carcinoma may be observed if one or both cellular types have undergone malignant degeneration. Myoepithelial carcinoma shows metastases via the hematogenous route rather than the lymphatogenous route [15]. Preoperative imaging findings are not distinctive. A preoperative diagnosis by FNAC may be difficult, therefore core needle biopsy may be more suitable. Mammotome biopsy has been recommended instead of core needle biopsy because the latter provides a smaller amount of tissue [9].

If carcinoma is diagnosed at the final pathological examination in a totally excised adenomyoepithelioma which was preoperatively thought to be benign, then the lesion should be reevaluated and treated as a carcinoma thereafter. The surgical treatment of a malignant tumor is similar to other invasive types of breast tumors. Wide local excision with negative margins or mastectomy with axillary dissection is the preferred treatment [16]. There is not enough information about role of chemotherapy, radiotherapy, or hormone therapy. The metastatic sites have been reported as axillary lymph nodes, lungs, brain, bones, and thyroid gland [17].

\section{Conclusion}

Although most adenomyoepithelial lesions are benign, malignant degeneration of one or both cellular components may occur. Preoperative diagnostic evaluation is important to avoid unnecessary wide surgical resections and mastectomies. Therefore, cytopathologists should pay attention to the cytologic appearance and immunocytochemical features of the lesion. Close follow-up is recommended by both radiologists and surgeons because of the potential for recurrence and even metastasis despite the lesion being reported as benign.

\section{Acknowledgements}

The authors would like to thank Nuran Sungu, MD for preparing the pathology illustrations. 


\section{References}

1 Rosen PP: Adenomyoepithelioma of the breast. Hum Pathol 1987;18:1232-1237.

2 Tsuda H, Mukai K, Fukutomi T, Hirohashi S: Malignant progression of adenomyoepithelial adenosis of the breast: Pathol Int 1994:44:475-479.

3 Tavassoli FA: Myoepithelial lesions of the breast Myoepitheliosis, adenomyoepithelioma, and myoepithelial carcinoma: Am J Surg Pathol 1991;15: 554-568.

4 Moinfar F: Adenosis; in Moinfar F (ed): Essentials of Diagnostic Breast Pathology. Berlin, Springer, 2007, p. 31.

5 Tsuji N, Tateishi R, Ishiguro S, Terao T, Higashiyama M: Adenomyoepitheloma of the lung. Am J Surg Pathol 1995;19:956-962.

6 Sciubba JJ, Brannon RB: Myoepithelioma of salivary glands: report of 23 cases. Cancer 1982;49: 562-572.

7 Pia-Foschini Mi, Reis-Filho JS, Eusebi V, Lakhani SR: Salivary gland-like tumours of the breast: surgical and molecular pathology. J Clin Pathol 2003;56: 497-506.
8 Rosen PP: Myoepithelial neoplasms; in Rosen PP (ed): Rosen's Breast Pathology. Philadelphia, Lippincott Williams and Wilkins, 2001,pp. 121-138.

9 Yahara T, Yamaguchi R, Yokoyama G, Yamaguchi M, Nakagawa S, Toh U, Shirouzu K, Kage M, Fujii T: Adenomyoepithelioma of the breast diagnosed by a mammotome biopsy: report of a case. Surg Today 2008:38:144-146.

10 Howlett DC, Mason CH, Biswas S, Sangle PD, Rubin G, Allan SM: Adenomyoepithelioma of the breast: spectrum of disease with associated imaging and pathology. AJR Am J Roentgenol 2003;180: 799-803.

11 Breitwieser C, Diekmann F, Diekmann S, Morawietz L, Taupitz M: Adenomyoepithelioma of the breast: MR mammography and histologic confirmation by MR guided vacuum assisted biopsy. European J Rad Extra 2005;53:59-62.

2 Iyengar P, Ali SZ, Brogi E: Fine needle aspiration cytology of mammary adenomyoepithelioma: a study of 12 patients. Cancer 2006;108:250-256.
13 Catena F, Santini D, Di Saverio S, Ansaloni L, Taffurelli M: Adenomyoepithelioma of the breast: an intricate diagnostic problem. Breast Care 2008;3: 125-127.

14 Nadelman CM, Leslie KO, Fishbein MC: Benign, metastasizing adenomyoepithelioma of the breast: a report of 2 cases. Arch Pathol Lab Med 2006;130: 1349-1353.

15 Ahmed AA, Heller DS: Malignant adenomyoepithelioma of the breast with malignant proliferation of epithelial and myoepithelial elements: a case report and review of the literature. Arch Pathol Lab Med 2000;124:632-636.

16 Woo EK, James AD, Mercer J, Allan SM, Howlet DC: Case report: myoepithelial carcinoma of the breast: a case report with imaging and pathological findings. Br J Radiol 2005;78:444-446.

17 Chen PC, Chen CK, Nicastri AD, Wait RB: Myoepithelial carcinoma of the breast with distant metastasis and accompanied by adenomyoepitheliomas. Histopathology 1994;24:543-548. 